\title{
PERAN DOSEN DALAM PENGEMBANGAN MASYARAKAT BUDDHA MELALUI PROGRAM PENGABDIAN KEPADA MASYARAKAT
}

\author{
Marjianto dan Platian \\ Kepenyuluhan Buddha, STABN Raden Wijaya \\ PGSD Buddha, STABN Raden Wijaya \\ antonmarjianto@gmail.com
}

\begin{abstract}
ABSTRAK
Penelitian ini bertujuan untuk mendeskripsikan peran dosen dalam pengembangan masyarakat Buddha melalui program pengabdian kepada masyarakat dan untuk menganalisis faktor yang menentukan keberhasilan pengembangan masyarakat buddha melalui program pengabdian kepada masyarakat. Pendekatan yang digunakan adalah pendekatan kualitatif. Teknik pengumpulan data melalui wawancara, observasi dan dokumentasi. Peran dosen dalam pengembangan masyarakat Buddha melalui program pengabdian kepada masyarakat berusaha meningkatkan dan memberdayakan masyarakat Buddha baik material dan spiritual. Secara material berusaha meningkatkan kesejahteraan sosial ekonomi masyarakat. Secara spiritual berusaha meningkatkan pengertian, pemahaman dan pengamalan ajaran Buddha. Beberapa faktor yang menentukan keberhasilan pengembangan masyarakat Buddha melalui program pengabdian kepada masyarakat yaitu: faktor dana, sasaran atau obyek pengabdian, lokasi, materi, dan metode.
\end{abstract}

Kata Kunci: Peran Dosen, Pengembangan, Masyarakat Buddha, Pengabdian Masyarakat.

\section{ABSTRACT}

This study aims to describe the role of lecturers in the development of Buddhist society through community service programs and to analyze what factors determine the success of the development of Buddhist society through community service programs. The approach used in this study is a qualitative approach. A particular phenomenon or event will have more meaning and meaning if it is described in words. Data collection techniques through interviews, observation and documentation. The role of lecturers in the development of Buddhist society through community service programs is trying to improve and empower the Buddhist community both materially and spiritually. Materially trying to improve the socio-economic welfare of the community. Spiritually trying to increase understanding and practice of Buddhism. There are several factors that determine the success of Buddhist community development through community service programs. Namely: funding or budgetary, target or service objects, location, material and method.

Key words: The Role of Lecturers, Development, Buddhist Communities, Community Service

\section{PENDAHULUAN}

$$
\begin{array}{ccc}
\text { Dosen di Perguruan } & \text { Tinggi } & \text { selain } \\
\text { mengajar mahasiswa, harus terus }
\end{array}
$$
mengembangkan ilmunya melalui penelitian, dan menerapkan hasil penelitian tersebut melalui pengabdian pada masyarakat. Berarti seorang dosen harus bertindak sebagai: Pengajar. Dosen bukan hanya menguasai materi kuliah dalam kelas, tetapi juga dapat mengajarkannya pada orang lain dengan metode yang baik. Dosen juga tidak hanya mengajarkan hal-hal keilmuan pada mahasiswa, tetapi juga sikap-sikap yang benar dalam menempuh kehidupan di masyarakat. Peneliti.

Dosen harus meneliti untuk mengembangkan keilmuannya. Bukan hanya untuk diri sendiri, tetapi juga merupakan bentuk tanggung jawab terhadap pengembangan ilmu pengetahuan yang 
dimilikinya. Sikap haus belajar dan selalu ingin tahu sangat diperlukan dosen untuk maju dan berkembang. Di Perguruan Tinggi luar negeri, sudah biasa bahwa sebagian besar penelitian terbaru muncul dari kampus, bukan industri atau tempat lain. Pelayan masyarakat. Dosen tidak cukup hanya tinggal di kampus, tetapi juga harus mau membumi dengan masyarakat yang membutuhkan bantuan. Sebagai tanggung jawab moral dan sosial terhadap masyarakat, dosen harus mau memberikan ilmu yang ia miliki untuk kepentingan orang banyak atau masyarakat

\section{Undang-undang Republik Indonesia} nomor 14 tahun 2005 tentang guru dan dosen pasal 1 ayat 2. Dosen adalah pendidik profesional dan ilmuwan dengan tugas utama mentransformasikan, mengembangkan, dan menyebarluaskan ilmu pengetahuan, tek:nologi, dan seni melalui pendidikan, penelitian, dan pengabdian kepada masyarakat. Pasal 3 ayat (1) dosen mempunyai kedudukan sebagai tenaga profesional pada jenjang pendidikan tinggi yang diangkat sesuai dengan peraturan perundang-undangan. Dan ayat pengakuan kedudukan dosen sebagai tenaga profesional sebagaimana dimaksud pada ayat (1) dibuktikan dengan sertifikat pendidik. Pasal 5 Kedudukan dosen sebagai tenaga profesional sebagaimana dimaksud dalam Pasal 3 ayat (1) berfungsi untuk meningkatkan martabat dan peran dosen sebagai agen pembelajaran, pengembang ilmu pengetahuan, teknologi, dan seni, serta pengabdi kepada masyarakat berfungsi untuk meningkatkan mutu pendidikan nasional.

Dosen dituntut untuk dapat melaksanakan Tri Darma Perguruan Tinggi yaitu melaksanakan pendidikan, melaksanakan penelitian dan melaksanakan pengabdian pada masyarakat. Dalam hal melaksanakan pengabdian kepada masyarakat dosen hendaknya dapat membantu mengembangkan peran masyarakat Buddha baik secara spiritual maupun material. Secara spiritual masih banyak dijumpai masyarakat buddha yang belum memahami ajaran maupun melaksanakan ajaran Buddha secara benar. Demikian juga dalam hal materi atau kebutuhan lahiriah masih dijumpai umat buddha yang hidup dalam keadaan memprihatinkan bahkan masih berada dibawah garis kemiskinan.

Pada kenyataannya dua hal yaitu kebutuhan jasmani atau materi dan kebutuhan spriritual tidak dapat berjalan sendiri-sendiri, tetapi harus berjalan bersama secara seimbang. Masyarakat buddha akan kuat keyakinannya atau spritualnya apabila didukung oleh materi yang yang cukup. Untuk dapat berdana keada Sangha membutuhkan materi atau uang. Untuk dapat membangun tempat ibadah juga membutuhkan uang atau materi. Untuk memperoleh pendidikan juga membutuhkan meteri atau uang. Dengan demikian materi atau uang dalam hal ini memang penting untuk dapat menunjang kebutuhan lainnya. Dalam hal tertentu tidak aneh apabila 
dimasyarakat Buddha terjadi pindah keyakinan hanya karena donasi dari masyarakat yang lain.

Setiap perguruan tinggi diharapkan dapat mengelola pengabdian kepada masyarakat berdasar Permenristekdikti Nomor 44 Tahun 2015 tentang Standar Nasional Pendidikan Tinggi terkait dengan ruang lingkup dan penjelasan Standar Nasional Pengabdian kepada Masyarakat sebagai berikut:

Pertama, Standar hasil pengabdian kepada masyarakat, merupakan kriteria minimal yang meliputi: a) hasil pengabdian kepada masyarakat dalam menerapkan, mengamalkan, dan membudayakan ilmu pengetahuan dan teknologi guna memajukan kesejahteraan umum dan mencerdaskan kehidupan bangsa; dan b) hasil pengabdian kepada masyarakat dapat berupa penyelesaian masalah yang dihadapi masyarakat dengan memanfaatkan keahlian sivitas akademik yang relevan, pemanfaatan teknologi tepat guna, bahan pengembangan ilmu pengetahuan dan teknologi atau bahan ajar atau modul pelatihan untuk pengayaan sumber belajar.

Kedua, standar isi pengabdian kepada masyarakat, merupakan kriteria minimal tentang: a) kedalaman dan keluasan materi pengabdian kepada masyarakat mengacu pada standar hasil pengabdian kepada masyarakat yaitu bersumber dari hasil penelitian atau pengembangan ilmu pengetahuan dan teknologi yang sesuai dengan kebutuhan masyarakat, dan b) hasil penelitian atau pengembangan ilmu pengetahuan dan teknologi yang dapat diterapkan langsung dan dibutuhkan oleh masyarakat pengguna, memberdayakan masyarakat, teknologi tepat guna yang dapat dimanfaatkan dalam rangka meningkatkan taraf hidup dan kesejahteraan masyarakat, model pemecahan masalah, rekayasa sosial, dan/atau rekomedasi kebijakan yang dapat diterapkan langsung oleh masyarakat, dunia usaha, industri, dan/atau Pemerintah, serta Kekayaan Intelektual (KI) yang dapat diterapkan langsung oleh masyarakat, dunia usaha, dan/atau industri.

Ketiga, Standar proses pengabdian kepada masyarakat, merupakan kriteria minimal tentang: a) kegiatan pengabdian kepada masyarakat yang terdiri atas perencanaan, pelaksanaan, dan pelaporan kegiatan; b) kegiatan pengabdian kepada masyarakat dapat berupa pelayanan kepada masyarakat, penerapan ilmu pengetahuan dan teknologi sesuai dengan bidang keahliannya, peningkatan kapasitas masyarakat; atau pemberdayaan masyarakat; c) pengabdian kepada masyarakat yang wajib mempertimbangkan standar mutu, menjamin keselamatan kerja, kesehatan, kenyamanan, serta keamanan pelaksana, masyarakat, dan lingkungan; d) kegiatan pengabdian kepada masyarakat yang dilakukan oleh mahasiswa sebagai salah satu dari bentuk pembelajaran harus mengarah pada terpenuhinya capaian pembelajaran lulusan serta memenuhi ketentuan dan peraturan di perguruan tinggi; dan e) kegiatan pengabdian kepada 
masyarakat yang harus diselenggarakan secara terarah, terukur, dan terprogram.

Keempat, standar penilaian pengabdian kepada masyarakat, merupakan kriteria minimal penilaian terhadap: a) proses dan hasil pengabdian kepada masyarakat; b) penilaian proses dan hasil pengabdian kepada masyarakat dilakukan secara terintegrasi dengan prinsip penilaian paling sedikit dari sisi edukatif, objektif, akuntabel, dan transparan; c) kesesuaian dengan standar hasil, standar isi, dan standar proses pengabdian kepada masyarakat; d) tingkat kepuasan masyarakat, terjadinya perubahan sikap, pengetahuan, dan keterampilan pada masyarakat sesuai dengan sasaran program, dapat dimanfaatkannya ilmu pengetahuan dan teknologi di masyarakat secara berkelanjutan, terciptanya pengayaan sumber belajar dan/atau pembelajaran serta pematangan sivitas akademika sebagai hasil pengembangan ilmu pengetahuan dan teknologi, serta teratasinya masalah sosial dan rekomendasi kebijakan yang dapat dimanfaatkan oleh pemangku kepentingan; dan e) dapat dilakukan dengan menggunakan metode dan instrumen yang relevan, akuntabel, dan dapat mewakili ukuran ketercapaian kinerja proses dan pencapaian kinerja hasil pengabdian kepada masyarakat.

Kelima, standar pelaksana pengabdian kepada masyarakat, merupakan kriteria minimal yang meliputi: a) kemampuan pelaksana untuk melaksanakan pengabdian kepada masyarakat; b) wajib memiliki penguasaan metode penerapan keilmuan yang sesuai dengan bidang keahlian, jenis kegiatan, serta tingkat kerumitan dan kedalaman sasaran kegiatan yang ditentukan berdasarkan kualifikasi akademik dan hasil pengabdian kepada masyarakat; dan c) kemampuan pelaksana pengabdian kepada masyarakat untuk menentukan kewenangan melaksanakan pengabdian kepada masyarakat yang diatur dalam pedoman rinci yang dikeluarkan oleh Direktur Jenderal Penguatan Riset dan Pengembangan.

Keenam, standar sarana dan prasarana pengabdian kepada masyarakat, merupakan kriteria minimal tentang: a) sarana dan prasarana yang diperlukan untuk menunjang proses pengabdian kepada masyarakat dalam rangka memenuhi hasil pengabdian kepada masyarakat yang ada di perguruan tinggi untuk memfasilitasi pengabdian kepada masyarakat yang terkait dengan penerapan bidang ilmu dari program studi yang dikelola perguruan tinggi dan area sasaran kegiatan; dan b) sarana dan prasarana pengabdian kepada masyarakat merupakan sarana perguruan tinggi yang dimanfaatkan juga untuk proses pembelajaran dan kegiatan penelitian serta harus memenuhi standar mutu, keselamatan kerja, kesehatan, kenyamanan, dan keamanan.

Ketujuh, standar pengelolaan pengabdian kepada masyarakat, merupakan kriteria minimal tentang: a) perencanaan, pelaksanaan, pengendalian, pemantauan dan evaluasi, serta pelaporan kegiatan pengabdian kepada masyarakat yang dilaksanakan oleh 
unit kerja dalam bentuk kelembagaan yang bertugas untuk mengelola pengabdian kepada masyarakat dengan bentuk lembaga penelitian dan pengabdian kepada masyarakat, atau bentuk lainnya yang sejenis sesuai dengan kebutuhan dan ketentuan perguruan tinggi; b) kelembagaan yang wajib untuk menyusun dan mengembangkan rencana program pengabdian kepada masyarakat sesuai dengan rencana strategis pengabdian kepada masyarakat perguruan tinggi, serta menyusun dan mengembangkan peraturan, panduan, dan sistem penjaminan mutu internal kegiatan pengabdian kepada masyarakat; c) kelembagaan yang dapat memfasilitasi pelaksanaan kegiatan pengabdian kepada masyarakat yang meliputi pelaksanaan pemantauan, evaluasi pelaksanaan, diseminasi hasil pengabdian kepada masyarakat; d) kelembagaan yang dapat memfasilitasi kegiatan peningkatan kemampuan pelaksana pengabdian kepada masyarakat, memberikan penghargaan kepada pelaksana pengabdian kepada masyarakat yang berprestasi, mendayagunakan sarana dan prasarana pengabdian kepada masyarakat pada lembaga lain melalui kerja sama; dan e) kemampuan lembaga untuk dapat melakukan analisis kebutuhan yang menyangkut jumlah, jenis, dan spesifikasi sarana dan prasarana pengabdian kepada masyarakat, serta menyusun dan menyampaikan laporan kegiatan pengabdian pada masyarakat yang dikelolanya ke pangkalan data pendidikan tinggi.
Kedelapan, standar pendanaan dan pembiayaan pengabdian kepada masyarakat, merupakan kriteria minimal: a) sumber dan mekanisme pendanaan dan pembiayaan pengabdian kepada masyarakat melalui dana internal perguruan tinggi, pendanaan pemerintah, kerja sama dengan lembaga lain, baik di dalam maupun di luar negeri, atau dana dari masyarakat; b) pengelolaan pendanaan pengabdian kepada masyarakat bagi dosen atau instruktur yang digunakan untuk membiayai perencanaan, pelaksanaan, pengendalian, pemantauan dan evaluasi, pelaporan, serta diseminasi hasil pengabdian kepada masyarakat; c) mekanisme pendanaan dan pembiayaan pengabdian kepada masyarakat yang harus diatur berdasarkan ketentuan di perguruan tinggi; d) perguruan tinggi wajib menyediakan dana pengelolaan termasuk peningkatan kapasitas pelaksana pengabdian kepada masyarakat; dan e) perguruan tinggi tidak dibenarkan untuk mengambil fee dari pelaksana pengabdian kepada masyarakat.

Dosen sebagai agen pembangunan tentu harus memikirkn bagaimana masyarakat Buddha dapat maju secara spiritual maupun material. Keyakinan masyarakat buddha akan tergerus apabila kebutuhan dasar yaitu sandang, pangan dan papan masih jadi hambatan. Sebaliknya keyakinan masyarakat buddha akan semakin kuat apabila kebutuhan dasar masyarakat dapat terpenuhi. Sehingga masyarakat mendapat motivasi yang tingggi untuk tetap melestarikan ajaran Buddha. 
Sebagai gambaran awal bahwa para dosen Sekolah Tingi Agama Buddha Negeri Raden Wijaya Wonogiri Jawa Tengah yang melakukan pengabdian kepada masyarakat pada tahun 2018 sebanyak 10 (sepuluh) kelompok pengabdian kepada masyarakat, masih terdapat pengabdian kepada masyarakat yang belum menyentuh kehidupan masyarakat bawah atau kelompok masyarakat miskin secara ekonomi maupun miskin ilmu keagamaan.atau spiritual.

Yang diharapkan adalah dosen dapat menyentuh dalam hal pengembangan masyarakat Buddha untuk meningkatkan kesejahteraan material dan spiritual. Kesejahteraan spiritual akan didapatkan dengan cara mempelajari, menghayati dan melaksanakan ajaran Buddha, sedangkan kesejahteraan material akan diperoleh jika tingkat penghasilan masyarakat meningkat minimal dapat memenuhi kebutuhan dasar hidup di masyarakat. Beradasarkan latar belakang tersebut, maka penulis merumuskan masalah sebagai berikut: 1). Bagaimana peran dosen dalam pengembangan masyarakat Buddha melalui program pengabdian kepada masyarakat?. 2). Faktor apa yang menentukan keberhasilan pengembangan masyarakat Buddha melalui program pengabdian kepada masyarakat?

Kedudukan Dosen, Undang-undang Republik Indonesia nomor 14 tahun 2005 tentang guru dan dosen, Pasal 3 ayat (1) dosen mempunyai kedudukan sebagai tenaga profesional pada jenjang pendidikan tinggi yang diangkat sesuai dengan peraturan perundang-undangan. Ayat (2) pengakuan kedudukan dosen sebagai tenaga profesional sebagaimana dimaksud pada ayat (1) dibuktikan dengan sertifikat pendidik. Pasal 5 Kedudukan dosen sebagai tenaga profesional sebagaimana dimaksud dalam Pasal 3 ayat (1) berfungsi untuk meningkatkan martabat dan peran dosen sebagai agen pembelajaran, pengembang ilmu pengetahuan, teknologi, dan seni, serta pengabdi kepada masyarakat berfungsi untuk meningkatkan mutu pendidikan nasional.

Arti Peran, Peran merupakan aspek dinamis kedudukan (status), apabila seseorang melaksanakan hak dan kewajibannya sesuai dengan kedudukannya, maka ia menjalankan suatu peranan. Soerjono Soekanto, (2002). Peran merupakan aspek dinamis dari kedudukan (status) yang dimiliki oleh seseorang, sedangkan status merupakan sekumpulan hak dan kewajiban yang dimiliki seseorang apabila seseorang melakukan hak-hak dan kewajiban-kewajiban sesuai dengan kedudukannya, maka ia menjalankan suatu fungsi.

Hakekatnya peran dapat dirumuskan sebagai suatu rangkaian perilaku tertentu yang ditimbulkan oleh suatu jabatan tertentu. Kepribadian seseorang juga mempengaruhi bagaimana peran itu harus dijalankan. Peran yang dimainkan hakekatnya tidak ada perbedaan, baik yang dimainkan / diperankan pimpinan tingkat atas, menengah maupun bawah akan mempunyai peran yang sama

Peran merupakan tindakan atau perilaku yang dilakukan oleh seseorang yang menempati suatu posisi di dalam status sosial, syarat-syarat peran mencangkup 3 
(tiga) hal, yaitu : 1).Peran meliputi normanorma yang dihubungkan dengan posisi atau tempat seseorang dalam masyarakat. Peranan dalam arti ini merupakan rangkaian peraturanperaturan yang membimbing seseorang dalam kehidupan kemasyarakatan. 2).Peran adalah suatu konsep perilaku apa yang dapat dilaksanakan oleh individu- individu dalam masyarakat sebagai organisasi. Peran juga dapat dikatakan sebagai perilaku individu, yang penting bagi struktur sosial masyarakat. 3). Peran adalah suatu rangkaian yang teratur yang ditimbulkan karena suatu jabatan.

Manusia sebagai makhluk sosial memiliki kecenderungan untuk hidup berkelompok. Dalam kehidupan berkelompok akan terjadi interaksi antara anggota masyarakat yang satu dengan anggota masyarakat yang lainnya. Tumbuhnya interaksi ada saling ketergantungan. Dalam kehidupan bermasyarakat itu munculah peran (role). Peran merupakan aspek yang dinamis dari kedudukan seseorang, apabila seseorang melaksanakan hak-hak dan kewajibannya sesuai dengan kedudukannya maka yang bersangkutan menjalankan suatu peranan. Miftah Thoha, (1997). Dari beberapa pengertian diatas, penulis menyimpulkan bahwa peran adalah suatu sikap atau perilaku yang diharapkan oleh banyak orang atau sekelompok orang terhadap seseorang yang memiliki status atau kedudukan tertentu.

Pengembangan masyarakat, diartikan sebagai komitmen dalam memberdayakan masyarakat lapis bawah sehingga masyarakat memiliki berbagai pilihan nyata menyangkut masa depan. Pengembangan masyarakat merupakan upaya mengembangkan sebuah kondisi masyarakat secara berkelanjutan dan aktif berlandaskan prinsip-prinsip keadilan sosial dan saling menghargai. Menurut Gordon G. Darkenwald dan Sharan B. Meriam, dalam (M.Toha). pengembangan masyarakat berintikan kegiatan sosial yang difokuskan untuk memecahkan masalahmasalah sosial. Dalam pengembangan masyarakat, batasan antara belajar dan bekerja sangat tipis, karena keduanya berjalan secara terpadu. Miftah Thoha, (1997).

Sedangkan menurut Twelvetrees pengembangan masyarakat adalah "the process of assisting ordinary people to improve their own communities by undertaking collective actions." Artinya upaya untuk membantu orang-orang dalam meningkatkan kelompok mereka sendiri dengan cara melakukan usaha bersama-sama. Maka dari itu, pengembangan masyarakat dapat diartikan sebagai upaya untuk memungkinkan individu maupun kelompok masyarakat untuk dapat memecahkan masalah-masalah sosial serta memiliki pilihan nyata yang menyangkut masa depannya sehingga dapat meningkatkan kualitas hidupnya.

$$
\text { Program-program pengembangan }
$$
masyarakat secara umum dimaksudkan untuk meningkatkan kualitas hidup masyarakat lapis bawah. Pengembangan masyarakat secara umum diaktualisasikan dalam beberapa tahapan mulai dari perencanaan, 
pengkoordinasian dan pengembangan berbagai langkah penanganan program kemasyarakatan. Program pengembangan masyarakat umumnya menekankan penerapan community-based management (CBM). Yaitu pendekatan pengelolaan program yang menjadikan pengetahuan dan kesadaran masyarakat lokal sebagai dasarnya. CBM diartikan sebagai suatu strategi untuk mewujudkan praktik pembangunan yang berpusat pada manusia, pusat pengambilan keputusan mengenai pemanfaatan sumberdaya secara berkelanjutan di suatu daerah berada di tangan organisasi-organisasi dalam masyarakat di daerah tersebut. Masyarakat diberikan kesempatan dan tanggung jawab dalam melakukan pengelolaan terhadap sumber daya yang dimilikinya. Moh Ali Aziz, (2009).

Pengembangan masyarakat mempunyai fungsi strategis selain mampu memunculkan kesadaran juga potensial menguatkan kapasitas (capacity buliding) sehingga masyarakat berdaya keluar dari jerat kondisi keertinggalan, keterbelakangan, kemerosotan moral, ketunaan, kebodohan, ketakberdayaan dan kemiskinan. Beberapa fungsi strategis dari pengembangan masyarakat menurut Suharto dalam Dumasari (2014) yaitu: a). Memberikan pelayanan sosial yang berbasis kepada masyarakat mulai dari pelayanan preventif untuk anak-anak sampai pelayanan kuratif dan pengembangan untuk keluarga yang berpendapatan rendah. b).Menolong anggota masyarakat yang memiliki kesamaan minat untuk bekerjasama, mengidentifikasi kebutuhan berasama dan kemudian melakukan kegiatan bersama untuk memenuhi kebutuhan mereka sendiri. c). Memenuhi kebutuhan orang-orang yang tidak beruntung atau tertindas, baik yang disebabkan oleh kemiskinan maupun oleh deskriminasi berdasarkan kelas sosial, suku, gender, jenis kelamin, usia dan kecacatan. d).Menekankan pentingnya swadaya dan keterlibatan informal dalam mendukung strategi penanganan kemiskinan dan penindasan termasuk memfasilitasi partisipasi warga agar aktif terlibat dalam pemberdayaan masyarakat. e).Meminimalisir kesenjangan dalam pemberian pelayanan, penghapusan deskriminasi dan ketelantaran melalui stategi pemberdayaan masyarakat. Dumasari, (2014)

Jadi pengembangan atau pemberdayaan masyarakat merupakan salah satu kegiatan penting yang perlu dilakukan dalam upaya untuk memberdayakan teruatama pada kelompok yang dinilai lemah dan rentang terhadap kemiskinan sehingga mereka memiliki kemampuan dan kekuatan serta dapat melepaskan diri mereka dari berbagai keterpurukan, ketertinggalan dan keterbelakangan dan dengan demikian keinginan mereka untuk menjadi suatu kelompok yang maju, mandiri dan terpenuhi segala kebutuhannya bisa tercapai. Hanya saja istilah pemberdayaan ini seringkali tumpang tindih dengan istilah pembangunan meski keduanya sesungguhnya memiliki kaitan erat satu sama lain namun bagaimana pun juga konsep pemberdayaan boleh dikata merupakan terjemahan dari kata "Empowerment" sedangkan kata 
pembangunan merupakan istilah yang diterjemahkan dari kata "Development".

Pengembangan masyarakat dalam hal ini penulis mendeskripsikan ke dalam dua hal yaitu pengembangan spiritual meliputi pengertian, pemahaman dan pengamalan ajaran Buddha dan pengembangan dalam hal material atau financial yaitu upaya untuk meningkatkan kesejahteraan masyarakat.

Pengabdian kepada masyarakat merupakan pelaksanaan pengamalan ilmu pengetahuan, teknologi dan seni budaya langsung pada masyarakat secara kelembagaan melalui metodologi ilmiah sebagai penyebaran Tri Dharma Perguruan Tinggi serta tanggung jawab yang luhur dalam usaha mengembangkan kemampuan masyarakat, sehingga dapat mempercepat laju pertumbuhan tercapainya tujuan pembangunan nasional.

Di dalam Pasal 24, Butir 2, UU. No. 20 Tahun 2003, tentang Sistem Pendidikan Nasional, telah dinyatakan bahwa Perguruan Tinggi memiliki otonomi untuk mengelola sendiri lembaganya sebagai pusat penyelenggaraan pendidikan tinggi, penelitian ilmiah, dan pengabdian kepada masyarakat. Program penelitian yang dilakukan di PT dituntut untuk menghasilkan produk yang benar-benar berkualitas dan bermanfaat. Sedangkan program pengabdian kepada masyarakat lebih diarahkan pada pemanfaatan dan penerapan hasil penelitian maupun hasil pendidikan di PT, untuk kesejahteraan dan kemajuan masyarakat.

Menurut buku Panduan Pelaksanaan Penelitian dan Pengabdian kepada
Masyarakat yang dikeluarkan oleh DP3M Dikti (2002), pengabdian kepada masyarakat oleh PT diartikan sebagai pengamalan ipteks yang dilakukan oleh PT secara melembaga melalui metode ilmiah langsung kepada masyarakat (di luar kampus yang tidak terjangkau oleh program pendidikan formal) yang membutuhkannya, dalam upaya menyukseskan pembangunan dan mengembangkan manusia pembangunan.

Pengabdian kepada masyarakat di Perguruan Tinggi dapat dipersepsi sebagai industri pelayanan, dikembangkan antara lain dalam bentuk Pendidikan kepada Masyarakat, Pelayanan kepada Masyarakat, Pengembangan Wilayah, Kaji Tindak (action research) dan Kuliah Kerja Nyata. Pengabdian kepada masyarakat merupakan salah satu jasa PT, dilaksanakan dengan menganut asas kelembagaan, asas ilmuamaliah dan amal-ilmiah, asas kerjasama, asas kesinambungan, serta asas edukatif dan pengembangan.

Tujuan yang ingin dicapai melalui kegiatan pengabdian kepada masyarakat adalah sebagai berikut: Bertambahnya kecepatan proses peningkatan kemampuan sumber daya manusia sesuai dengan laju pertumbuhan pembangunan. Bertambahnya kecepatan upaya pengembangan masyarakat ke arah terbinanya masyarakat yang harmonis serta dinamis yang siap menempuh perubahan-perubahan menuju perbaikan dan kemajuan sesuai dengan nilai-nilai sosial budaya dan norma-norma dalam kehidupan masyarakat berkembang dalam kehidupan masyarakat yang berlaku.Bertambahnya 
kecepatan usaha pembinaan institusi dan profesi masyarakat sesuai dengan laju pertumbuhan proses modernisasi dalam kehidupan masyarakat itu sendiri. Untuk memperoleh umpan balik dan masukan bagi perguruan tinggi dalam rangka meningkatkan relevansi pendidikan, diperlukan adanya ahliahli yang memiliki kemampuan secara interdisipliner dan multidisipliner.

\section{METODE}

Jenis penelitian yang digunakan adalah jenis penelitian deskriptif dengan pendekatan kualitatif. Pendekatan kualitatif menurut Bogdan dan Taylor adalah sebagai prosedur penelitian yang menghasilkan data deskriptif berupa kata-kata tertulis atau lisan dari orang-orang dan perilaku yang dapat diamati (Moleong, 2000)

Penelitian Kualitatif pada hakekatnya adalah mengamati orang dalam lingkungan hidupnya, berinteraksi dengan mereka, berusaha memahami bahasa dan tafsiran mereka tentang dunia sekitarnya. (Nasution, 1988). Dengan metode kualitatif maka data yang didapat akan lebih lengkap, lebih mendalam, kredibel dan bermakna sehingga tujuan penelitian dapat dicapai. Melalui penggunaan metode kualitatif akan diperoleh data yang lebih tuntas, pasti, sehingga memiliki kredibilitas yang tinggi. Permasalahan dalam penelitian ini lebih tepat dicarikan datanya dengan metode kualitatif.

Untuk mendapatkan data yang akurat dan dapat dipertanggung jawabkan, maka teknik pengumpulan data yang dilakukan melalui beberapa tahap sesuai dengan teknik pengumpulan data yaitu wawancara mendalam, observasi, dokumentasi. Analisis data kualitatif dilakukan secara interaktif dan berlangsung secara terus menerus pada setiap tahapan penelitian sehingga sampai tuntas, dan datanya sampai jenuh. Aktivitas dalam analisis data yaitu melalui proses data reduction, data display dan verification.

Pengujian kredibilitas data dilakukan dengan cara sebagai berikut: Perpanjangan Pengamatan, apabila satu periode data yang diperoleh dianggap belum memadahi dan belum kredibel, maka akan dilakukan perpanjangan pengamatan sampai data yang diperoleh dianggap telah jenuh. Meningkatkan Ketekunan, meningkatkan ketekunan berarti melakukan pengamatan secara lebih cermat dan berkesinambungan. Dengan cara tersebut maka kepastian data dapat direkam secara pasti dan sistematis. Dalam meningkatkan ketekunan peneliti dikakukan dengan cara membaca berbagai referensi buku maupun hasil penelitian yang terkait dengan temuan yang diteliti. Dengan membaca maka wawasan peneliti akan semakin luas dan tajam, sehingga dapat digunakan untuk memeriksa data yang ditemukan itu benar atau tidak.

Triangulasi dilakukan dengan cara triangulasi teknik, sumber data dan waktu. Triangulasi teknik dilakukan dengan cara menanyakan hal yang sama dengan teknik berbeda. Triangulasi sumber data dilakukan dengan cara menanyakan hal yang sama melalui sumber yang berbeda. Triangulasi 
waktu artinya pengumpulan data dilakukan pada berbagai kesempatan pagi, siang dan sore hari. Dengan Triangulasi dalam pengumpulan data tersebut maka dapat diketahui apakah narasumber memberikan data yang sama atau tidak. Kalau nara sumber memberikan data yang berbeda, berarti datanya belum kredibel.

\section{HASIL PENELITIAN DAN} PEMBAHASAN

Pengabdian kepada masyarakat bagi dosen merupakan pelaksanaan pengamalan ilmu pengetahuan, teknologi dan seni budaya langsung pada masyarakat secara kelembagaan melalui metodologi ilmiah sebagai pengamalan Tri Dharma Perguruan Tinggi serta tanggung jawab yang luhur dalam usaha mengembangkan kemampuan masyarakat, sehingga dapat mempercepat laju pertumbuhan tercapainya tujuan pembangunan nasional. Perguruan Tinggi Keagamaan Buddha Negeri (PTKBN) yang ada yaitu STABN Raden Wijaya terletak di Kabupaten Wonogiri Jawa Tengah dan STABN Sriwijaya terletak di Kota

Tangerang Banten, telah melaksanakan program pengabdian masyarakat bagi dosen di Jawa Tengah. Untuk mengetahui keberhasilan program tersebut dan faktorfaktor yang mempengaruhi, penulis melaksanakan pengamatan dan wawancara dengan pemuka atau tokoh agama daerah tersebut.

1. Pengabdian kepada masyarakat bagi dosen yang dilaksanakan di Kabupaten
Banyumas, Jawa Tengah, berdasarkan pengamatan dan wawancara tokoh agama Buddha di Kabupaten Banyumas mengatakan bahwa:

"Program pengabdian masyarakat bagi dosen untuk masyarakat Budhha di Kabupaten Banyumas sangat baik, tujuannya adalah membantu meningkatkan kesejahteraan masyarakat buddha di Banyumas melalui bantuan dan pelatihan pengolahan limbah plastik menjad biji plastik. Hanya saja karena mesin produksi nya relatif kecil, sehingga biaya produksi tidak seimbang dengan hasil penjualan".

Dengan demikian bantuan mesin pengolah biji plastik belum dapat dioptimalkan penggunaannya karena biaya produksi yang terdiri dari biaya pembelian limbah plastik dan ongkos tenaga kerja lebih besar dari pada hasil penjualannya. Oleh karena itu tujuan untuk meningkatkan kesejahteraan masyarakat belum berhasil. Yang menjadi kendala adalah bahan baku limbah plastik harus dibeli dari pengumpul atau pemulung sampah plastik dan tenaga kerja untuk menggiling atau memproduksi harus dibayar secara harian atau per hari. Setelah dihitung biaya produksi dengan hasil penjualan belum mendapat selisih keuntungan dan malah cendrung rugi.

Selain itu bentuk pengabdian masyarakat di Kabupaten Banyumas yang diberikan kepada kelompok kerja Guru Agama Buddha dan generasi muda Buddhis, dalam bentuk pelatihan membaca kitab suci sangat baik. Generasi muda Buddhis dan Guru Agama Buddha, dapat membaca kitab suci dengan baik, 
Hanya saja bantuan yang diberikan berupa media pembelajaran belum dapat dimanfaatkan secara maksimal karena dipegang atau dikuasai oleh salah seorang pengurus.

2. Pengabdian kepada masyarakat bagi dosen yang dilaksanakan di Kabupaten Kebumen, Jawa Tengah, berdasarkan pengamatan dan wawancara tokoh agama Buddha di Kabupaten Kebumen bantuan dan pelatihan penanaman pada pekarangan rumah berupa jambu air jenis delima. Tokoh agama Buddha mengatakan bahwa:

\begin{abstract}
"bantuan sangat bermanfaat bagi umat Buddha karena bibit jambu air dapat tumbuh di lahan pekarangan rumah dengan subur, dan menghasilkan buah yang manis, sehingga dapat memberi manfaat bagi umat Buddha, hanya saja kendalanya adalah jumlah bibit yang diterima masih terbatas jumlahnya dan membutuhkan perawatan yang teliti dan sabar".
\end{abstract}

Jenis tanaman jambu delima memang membutuhkan perawatan yang baik, misalnya menyemprot hama ulat, jamur dan jenis serangga lainnya. Karena yang dibantu adalah masyarakat petani, sehingga dalam mengatasi hal itu tidak terlalu sulit. Dengan demikian bibit jambu yang ditanamnya dapat meberikan hasil atau buah yang manis.

3. Pengabdian kepada masyarakat bagi dosen yang dilaksanakan di Kabupaten Boyolali, Jawa Tengah, berdasarkan pengamatan dan wawancara tokoh agama Buddha di Kabupaten Boyolali bantuan dan pelatihan pembuatan roti/kue kering. Salah satu tokoh wanita Budhis mengatakan bahwa:

"Bantuan berupa pelatihan usaha roti dan kue kering adalah sangat membantu pengetahuan dan ketrampilan umat Buddha, hanya kendalanya adalah dalam hal pemasaran usaha tersebut, bahwa untuk membuat roti bahan baku harus dibeli, tenaga harus dihitung kemudian kemasan dan lainnya. Jadi kalau dijual dengan harga murah merugi tapi dijual agak mahal tidak laku, dan bahkan untuk usaha itu sekarang ini harus bersaing dengan penjual online".

Oleh karena itu usaha membuat roti tidak dapat berlanjut karena tidak laku atau susah menjualnya paska produksi. Oleh karena itu bantuan berupa alat atau mesin pembuat roti atau oven akhirnya tidak terpakai untuk usaha. Hanya sesekali digunakan apabila ada anggota yang membutuhkan maka dipinjamkan untuk membuat kue atau roti.

4. Pengabdian kepada masyarakat bagi dosen yang dilaksanakan di Kabupaten Temanggung, Jawa Tengah. Berdasarkan pengamatan dan wawancara tokoh agama Buddha di Kabupaten Temanggung bantuan dan pelatihan ketrampilan musik angklung. Tokoh agama Buddha di Temanggung mengatakan bahwa:

"Pelatihan dan pemberian musik angklung bantuan dari pengabdian masyarakat dosen masih dirasakan manfaatnya. Anak-anak dapat memainkan musik angkulung sehingga dapat dipentaskan setiap ada momen atau acara keagamaan. Misalnya 
peringatan hari Waisak dan lainnya".

Selain itu juaga ada pengabdian dosen berupa bantuan pengelolaan hasil pertanian berupa pembuatan keripik pisang, singkong dan lainnya. Memang hal itu sangat membantu umat Buddha yang hampir semuanya adalah berprofesi sebagai petani. Tetapi kendala yang dihadapi adalah dalam hal pemasaran produk hasil tersebut. Singkatnya susah dalam memasarkan hasil produk, akhirnya berhenti. Masih dibutuhkan tindak lanjut berikutnya adalah manajemen atau cara memasarkan hasil produk tersebut.

5. Pengabdian kepada masyarakat bagi dosen yang dilaksanakan di Kabupaten Pati, Jawa Tengah.

Berdasarkan pengamatan dan wawancara tokoh agama Buddha di Kabupaten Pati bantuan dan pelatihan pembuatan web site bagi pengurus vihara. Tujuan program ini tentu sangat bagus agar vihara dapat memiliki website sehingga vihara dapat mempromosikan atau menunjukkan jati dirinya lebih mudah. Melalui wawancara tokoh agama Buddha di Pati mengatakan bahwa: "dalam proses pelatihan memang berjalan lancar, tetapi dalam tahap aplikasi atau penerapannya banyak mengalami kendala atau hambatan. Hambatan pertama adalah terkendalanya jaringan wifi untuk internet. Karena tidak semua vihara mampu mempunyai jaringan wifi”.
Dengan demikian terkendala dengan jaringan internet. Kendala yang lain adalah sumber daya manusia pengurus vihara untuk mengoperasikan jaringan internet khususnya megoperasionalkan website. Dengan demikian kelanjutan pengabdian masyarakat untu pelatihan website ini belun berhasil maksimal. Program ini telah dilaksanakan oleh kelompok dosen dari Sekolah Tinggi Agama Buddha Negeri Sriwijaya Tangerang Banten di Kabupaten Pati.

Selain itu terdapat program pelatihan bagi guru agama Buddha untuk melaksanakan penelitian tindakan kelas (PTK) oleh kelompok dosen Sekolah Tinggi Agama Buddha Negeri Raden Wijaya Wonogiri Jawa Tengah. Program ini dapat diterima dengan senag oleh kelompok kerja guru agama Buddha (KKG) kabupaten Pati. Pelatihan dapat diikuti dengan serius dan antusias. Dalam aplikasi atau tindak lanjutnya guru terkendala dengan motivasi pribadi karena penelitian tindakan kelas ini hanya terasa rmanfaatnya oleh guru yang akan naik pangkat ke golongan IV (empat). Dengan demikian bagi guru yang tidak berkepentingan untuk naik pangkat merasa malas untuk melakukan penelitian ini dan memplubikasikannya. Selain daripada itu kendala yang muncul adalah menurut informasi dari salah saru anggota KKG, bantuan operasional penunjang pendidikan hanya dikuasai 
oleh seorang saja, tidak dapat digunakan secara bersama.

6. Pengabdian kepada masyarakat bagi dosen yang dilaksanakan di Kabupaten Jepara, Jawa Tengah.

Berdasarkan pengamatan dan wawancara tokoh agama Buddha di Kabupaten Jepara, Jawa Tengah mengatakan bahwa: "bantuan dan pelatihan ketrampilan menulis karya ilmiah bagi kelompok kerja guru agama Buddha dan guru sekolah minggu buddha sangat membantu bagi guru yang akan naik pangkat melalui pengumpulan angka kredit.

Hal ini juga oleh kelompok dosen Sekolah Tinggi Agama Buddha Negeri Raden Wijaya Wonogiri Jawa Tengah. Program ini dapat diterima dengan senang oleh kelompok kerja guru agama Buddha dan kelompok guru sekolah minggu Buddha kabupaten Jepara. Pelatihan dapat diikuti dengan serius dan antusias.

Dalam tindak lanjutnya untuk melaksanakan penulisan karya ilmiah guru terkendala dengan motivasi karena karya ilmiah ini hanya terasa rmanfaatnya oleh guru yang akan naik pangkat, dengan demikian yang tidak berkepentingan dalam kenaikan pangkat tidak merasa perlu untuk menulis. Begitu juga bagi kelompok guru sekolah minggu Buddha.

Pengabdian bagi masyarakat dosen di Jawa Tengah oleh dua perguruan tinggi keagamaan Buddha negeri terdapat 21 lokasi pengabdian masyarakat, melibatkan 52 orang dosen, dan total nilai pengabdian masyarakat mencapai $\mathrm{Rp}$. 513.000.000 (Lima Ratus Tiga Belas Juta Rupiah). Sedangkan obyek sararan pengabdian meliputi: Umat Buddha, Generasi muda Buddha, kelompok kerja guru agama Buddha, penyuluh agama Buddha, guru sekolah minggu Buddha, pengurus vihara atau majelis agama Buddha dan organisasi wanita Buddha.

Dosen di perguruan tinggi selain melaksanakan tugas mengajar, harus terus mengembangkan ilmunya melalui penelitian, dan menerapkan hasil penelitian tersebut melalui pengabdian pada masyarakat. Sebagai pengajar, dosen bukan hanya menguasai materi, tetapi juga dapat mengajarkannya pada orang lain dengan metode yang baik. Dosen juga tidak hanya mengajarkan hal-hal keilmuan pada mahasiswa, tetapi juga sikap-sikap yang benar dalam menempuh kehidupan. Sebagai peneliti, dosen harus meneliti untuk mengembangkan keilmuannya. Bukan hanya untuk diri sendiri, tetapi juga merupakan bentuk tanggung jawab terhadap pengembangan ilmu pengetahuan yang dimilikinya. Sikap haus belajar dan selalu ingin tahu sangat diperlukan dosen untuk maju dan berkembang. Sebagai pelayan masyarakat, dosen tidak cukup hanya tinggal di kampus, tetapi juga harus mau bersama masyarakat yang membutuhkan bantuan. Sebagai tanggung jawab moral dan sosial 
terhadap masyarakat, dosen harus mau memberikan ilmu yang ia miliki untuk kepentingan masyarakat atau orang banyak. Dari uraian di atas, jelas bahwa dosen harus melakukan ketiganya dalam profesinya. Dengan penelitian, dosen akan memperkaya khasanah ilmu, dengan pengabdian masyarakat dosen dapat menjadi penggerak pembangunan.

Setiap perguruan tinggi diharapkan dapat mengelola pengabdian kepada masyarakat berdasar Permenristekdikti Nomor 44 Tahun 2015 tentang Standar Nasional Pendidikan Tinggi terkait dengan ruang lingkup dan penjelasan Standar Nasional Pengabdian kepada Masyarakat. Standar hasil pengabdian kepada masyarakat, merupakan kriteria minimal yang meliputi: a) hasil pengabdian kepada masyarakat dalam menerapkan, mengamalkan, dan membudayakan ilmu pengetahuan dan teknologi guna memajukan kesejahteraan umum dan mencerdaskan kehidupan bangsa; dan b) hasil pengabdian kepada masyarakat dapat berupa penyelesaian masalah yang dihadapi masyarakat dengan memanfaatkan keahlian sivitas akademik yang relevan, pemanfaatan teknologi tepat guna, bahan pengembangan ilmu pengetahuan dan teknologi atau bahan ajar atau modul pelatihan untuk pengayaan sumber belajar.

Standar pelaksana pengabdian minimal yang meliputi: a) kemampuan pelaksana untuk melaksanakan pengabdian kepada masyarakat; b) wajib memiliki penguasaan metode penerapan keilmuan yang sesuai dengan bidang keahlian, jenis kegiatan, serta tingkat kerumitan dan kedalaman sasaran kegiatan yang ditentukan berdasarkan kualifikasi akademik dan hasil pengabdian kepada masyarakat; dan c) kemampuan pelaksana pengabdian kepada masyarakat untuk menentukan kewenangan melaksanakan pengabdian kepada masyarakat yang diatur dalam pedoman rinci yang dikeluarkan oleh Direktur Jenderal Penguatan Riset dan Pengembangan

Tujuan pengabdian kepada masyarakat di perguruan tinggi adalah: melaksanakan pengabdian kepada masyarakat yang sesuai dengan Permenristekdikti No. 44 Tahun 2015 tentang Standar Nasional Pendidikan Tinggi; mengembangkan model pemberdayaan masyarakat; meningkatkan kapasitas pengabdian kepada masyarakat; memberikan solusi berdasarkan kajian akademik atas kebutuhan, tantangan, atau persoalan yang dihadapi masyarakat, baik secara langsung maupun tidak langsung; melakukan kegiatan yang mampu memberdayakan masyarakat pada semua strata, secara ekonomi, politik, sosial, dan budaya; dan melakukan alih teknologi, ilmu, dan seni kepada masyarakat untuk pengembangan martabat manusia

kepada masyarakat, merupakan kriteria 
berkeadilan gender dan inklusi sosial serta

kelestarian sumber daya alam.

Selain uraian di atas, tujuan yang hendak dicapai melalui kegiatan pengabdian kepada masyarakat adalah sebagai berikut: a). Bertambahnya kecepatan proses peningkatan kemampuan sumber daya manusia sesuai dengan laju pertumbuhan pembangunan.

b). Bertambahnya kecepatan upaya pengembangan masyarakat ke arah terbinanya masyarakat yang harmonis serta dinamis yang siap menempuh perubahan-perubahan menuju perbaikan dan kemajuan sesuai dengan nilai-nilai sosial budaya dan norma-norma dalam kehidupan masyarakat berkembang dalam kehidupan masyarakat yang berlaku. c). Bertambahnya kecepatan usaha pembinaan institusi dan profesi masyarakat sesuai dengan laju pertumbuhan proses modernisasi dalam kehidupan masyarakat itu sendiri. d). Untuk memperoleh umpan balik dan masukan bagi fakultas dalam rangka meningkatkan relevansi pendidikan, diperlukan adanya ahli-ahli yang memiliki kemampuan secara interdisipliner dan multidisipliner.

Sasaran pengabdian kepada masyarakat adalah sebagai berikut: a). Masyarakat luar kampus yang memerlukan bantuan dan petunjuk untuk meningkatkan kemampuan dalam pemecahan masalah untuk menunjang pembangunan. Yang diutamakan adalah mereka yang memiliki kedudukan diutamakan strategis dalam lapiran masyarakat, yaitu antara lain unsur-unsur pimpinan, pemuda atau remaja yang mampu melipatgandakan dan menyebarluaskan hasil kegiatan pengabdian pada masyarakat. b). Masyarakat pendidikan khusus, yang sesuai dengan prioritas dalam bidang sains, kependudukan dan lingkungan hidup, serta lembaga pendidikan dan lembaga masyarakat yang memerlukan pembinaan dan pengembangan secara khusus.

Kegiatan pengabdian kepada masyarakat secara umum meliputi ruang lingkup sebagai berikut: a). Pengembangan ilmu pengetahuan teknologi dan seni menjadi produk yang secara langsung dapat dimanfaatkan oleh masyarakat. b). Penyebarluasan ilmu pengetahuan, teknologi dan seni budaya menjadi produk yang perlu diketahui dan dimanfaatkan oleh masyarakat. Usaha ini dapat dilakukan melalui berbagai cara seperti memberikan penyuluhan, menyediakan percontohan, memperagakan, dan menerbitkan media publikasi. c). Penempatan ilmu pengetahuan dan teknologi secara benar dan tepat sesuai dengan situasi masyarakat dan tuntutan pembangunan. d). Pemberian bantuan kepada masyarakat dalam mengidentifikasi masalah yang dihadapi serta mencari alternatif pemecahannya dengan mempergunakan pendekatan ilmiah. e). Pemberian jasa pelayanan profesional kepada masyarakat 
dalam berbagai bidang permasalahan yang memerlukan penanganan secara cermat dengan menggunakan keahlian dan keterampilan yang belum dimiliki oleh masyarakat yang bersangkutan.

Berdasarkan tujuan yang ingin dicapai, program pengabdian kepada masyarakat dapat dibedakan menjadi lima bentuk, sebagai berikut:

a). Pendidikan Pada Masyarakat; Kegiatan pendidikan pada masyarakat dapat berbentuk pendidikan nonformal dalam rangka pendidikan kesinambungan (contuining education). Pelaksanaan dapat dilakukan dalam berbagai jenis, baik yang bersertifikat maupun yang tidak. Jenisjenis program pengabdian pada masyarakat meliputi penataan, loka karya, kursus-kursus, penyuluhan-penyuluhan, kampanye, publikasi-publikasi, proyekproyek, percontihan, dan demonstrasi seperti pameran.

b). Pelayanan Pada Masyarakat; Pelayanan pada masyarakat di sini ialah pemberian pelayanan secara profesional oleh perguruan tinggi kepada masyarakat yang memerlukannya. Pelayanan profesional yang dimaksud, bukan penelitian ilmiah tetapi lebih berupa pekerjaan rutin yang penanganannya perlu oleh tenaga profesional. Jenis-jenis program pengabdian pada masyarakat yang termasuk dalam bentuk pelayanan pada masyarakat meliputi konsultasi, bimbingan karier, pelayanan olah raga, pembinaan kesadaran terhadap lingkungan hidup, pembinaan koperasi, pembinaan kewiraswastaan dan sumber daya, pelayanan rintisan dalam bentukbentuk keahlian khusus dan sejenisnya.

c). Kuliah Kerja Mahasiswa (KKM); Kuliah kerja mahasiswa merupakan bentuk kegiatan pada masyarakat yang bersifat khusus karena dalam kuliah kerja mahasiswa dharma pendidikan dan penelitian dipadukan ke dalamnya serta melibatkan sejumlah mahasiswa dan staf pengajar yang banyak. Jenis-jenis program pengabdian pada masyarakat yang termasuk dalam bentuk program kuliah kerja mahasiswa meliputi bidang kewiraswastaan (ekonomi), sarana dan prasarana, produksi, pendidikan, sosial budaya, akuntansi dan kependudukan.

d). Pengembangan Wilayah Secara Terpadu; Pengembangan wilayah secara terpadu merupakan bentuk kegiatan pengabdian pada masyarakat yang menghasilkan konsep atau pola perencanaan pembangunan wilayah secara terpadu dan bersifat komprehensif yang secara langsung menunjang proses pembangunan. Untuk melaksanakan kegiatan semacam ini fakultas memiliki ahli yang telah memiliki ilmu pengetahuan secara baik, dan dapat menghimpun berbagai ahli untuk bekerja sama secara baik, dan bekerja sama secara interdisipliner dan multidisipliner.

e). Pengembangan Hasil Penelitian; Karena semua hasil penelitian terjadi dalam bentuk yang siap untuk dilaksanakan dan dimanfaatkan oleh masyarakat, perlu ada upaya-upaya untuk 
mengembangkan hasil penelitian tersebut menjadi produk baru yang lebih siap untuk dimanfaatkan oleh masyarakat. Produk hasil pengembangan itu dapat berupa pengetahuan terapan atau teknologi yang siap pakai dan hasilnya dirasakan oleh masyarakat pemakai. Jenis-jenis program pengabdian pada masyarakat yang berbentuk program pengembangan hasil penelitian meliputi program kaji tindak atau action research, program yang dikembangkan dari hasil penelitian sehingga menghasilkan produk baru yang berupa pengetahuan terapan, atau teknologi dan seni siap pakai.

Program pengabdian kepada masyarakat terintegrasi mendasarkan pelaksanaan pengabdiannya kepada prinsip-prinsip sebagai berikut:

1). Partisipasi; Melibatkan masyarakat secara aktif sebagai subyek di dalam suatu program, mulai dari perancangan, pelaksanaan, monitoring, evaluasi, pelaporan, dan diseminasi. 2). Pemberdayaan; Memperhatikan pengetahuan, pengalaman, kebutuhan, dan kehendak serta mendayagunakan potensi yang dimiliki masyarakat mitra pengabdian untuk mengembangkan dan memanfaatkan potensi yang dimiliki serta menyelesaikan persoalan-persoalan yang mereka hadapi. 3). Inklusifitas; Bersedia menerima keragaman dan perbedaan serta mengakomodasinya dalam berbagai tatananyang ada di masyarakat.Keragaman dimaksud meliputi antara lain keragamanagama, kepercayaan, budaya, adat, bahasa, gender, ras, suku bangsa, strata ekonomi, dan perbedaan kemampuan fisik/mental. 4). Kesetaraan dan Keadilan Gender; Memberikan akses, partisipasi, dan kontrol terhadap pengambilan keputusan, dan manfaat yang sama kepada perempuan dan laki-laki dalam program dan kegiatan Pengabdian kepada Masyarakat dan melaksanakan berbagai pendekatan yang mendorong kesetaraan dan menghilangkan kesenjangan. 5). Ramah Lingkungan; Memberi perhatian yang proporsional pada aspek-aspek tatakelola lingkungan hidup dan sumberdaya alam baik untuk menghindari atau menekan dampak lingkungan yang negatif maupun untuk secara proaktif memanfaatkan setiap peluang untuk meningkatkan kesehatan dan kelestarian lingkungan hidup dan sumberdaya alam. $6)$. Akuntabilitas; Mempertanggungjawabkan semua program dan kegiatan pengabdian kepada masyarakat kepada pemangku kepentingan sesuai dengan ketentuan peraturan yang berlaku dan prinsip-prinsip tatakelola yang baik dan demokratis. 7). Transparansi; Terbuka dalam menyajikan informasi dan laporan serta menerima masukan terkait program pengabdian kepada masyarakat. 8). Kemitraan; Menjalin kerjasama dan jejaring pengabdian kepada masyarakat dengan berbagai pihak berdasarkan kesetaraan, keterbukaan dan saling menguntungkan. 9). Keberlanjutan; Merancang bantuan 
pengabdian kepada masyarakat terintegrasi secara berkelanjutan dan mandiri dengan atau tanpa bantuan dari pihak manapun. 10). Kesukarelaan; Bersedia melakukan program dan kegiatan pengabdian kepada masyarakat tanpa paksaan, baik atas prakarsa sendiri maupun atas permintaan masyarakat dan pihak lain. 11). Manfaat; Setiap program dan kegiatan pengabdian kepada masyarakat harus bermanfaat seluasluasnya bagi semua pihak, baik dari segi keilmuan,sosial, ekonomi, politik, budaya dan manfaat lainnya bagi pengembangan masyarakat ke depan.Manfaat pengabdian adalah untuk mendorong masyarakat mengembangkan asset mereka. 12). Keterkaitan ilmu, amal dan transformasi sosial; Menjadikan program dan kegiatan pengabdian kepada masyarakat sebagai implementasi dari pembelajaran dan penelitian untuk mendukung transformasi sosial.

Pengabdian Kepada Masyarakat Terintegrasi di lingkungan PTKB harus mampu menerjemahkan ajaran-ajaran keagamaan dalam konteks perubahan sosial. Sehingga praktek keberagamaan masyarakat (secara individu maupun kolektif) diharapkan akan mengalami perubahan. Pengamalan ajaran-ajaran agama mengalami perubahan dari posisi yang masih sangat kental dengan nuansa tekstual dan simbolik (ritual), menuju perubahan bahwa pengamalan agama mampu memberikan inspirasi dan pencerahan untuk penyelesaian problem kehidupan sosial.

Perguruan tinggi mempunyai tugas "menantang" agar praktek keberagamaan masyarakat mampu menciptakan komitmen moral yang kuat sebagai landasan penyelesaian atas problem kehidupan sosial umat. Di sinilah, program pengabdian harus mampu menggeser paradigma normatif dalam keilmuan Buddha menuju kegiatan pengabdian yang bersifat memberdayakan. Pengabdian untuk menumbuhkan tradisi kritis perlu didorong, sehingga terjadi produksi ilmu pengetahuan sosial keagamaan makin banyak.

Banyak faktor yang mempengaruhi keberhasilan pengembangan masyarakat melalui program pengabdian kepada masyarakat. Dalam hal ini penulis mengelompokkan ada dua bidang keberhasilan yaitu secara material dan spiritual. Secara material indikatornya adalah meningkatnya kualitas hidup masyarakat secara material, disertai dengan terpetakannya masalah dan potensi yang ada di masyarakat, meningkatnya kesadaran kritis dan pengetahuan masyarakat, terkelolanya potensi yang dimiliki oleh masyarakat dengan baik. Sedangkan secara spiritual indikatornya adalah meningkatnya pengertian, pemahaman dan pelaksanaan masyarakat terhadap ajaran Buddha. Selanjutnya bagi masyarakat diakuinya Perguruan Tinggi Keagamaan Buddha 
(PTKB) sebagai kampus yang peduli dan bermutu di bidang pemberdayaan masyarakat, dijadikan sebagai destinasi tempat belajar oleh masyarakat.

Selain itu beberapa faktor yang menentukan keberhasilan pengembangan masyarakat Buddha melalui program pengabdian kepada masyarakat adalah: a). Faktor dana atau subyek dampingan; besar kecilnya dana yang digunakan turut menentukan keberhasilan pengembangan masyarakat dalam pengabdian kepada masyarakat. Contoh bantuan mesin pengolah biji plastik yang diberikan karena terlalu kecil sehingga hasil produksi juga kecil sehingga tidak sesuai dengan ongkos produksi. Apabila mesin produksi tersebut diberikan yang agak besar maka hasil produksi lebih besar dan ongkosnya produksi lebih kecil. Dengan demikian usaha dapat berjalan lancar. b). Faktor sasaran atau obyek pengabdian; Sasaran atau obyek pengabdian pada umumnya adalah masyarakat kurang mampu baik secara sosial ekonomi maupun pengetahuan, karena tujuan pengabdian masyarakat tujuannya adalah meningkatkan dan memberdayakan masyarakat kurang mampu. c). Faktor lokasi; lokasi pengabdian pada masyarakat sebaiknya memilih lingkungan masyarakat yang jauh tertinggal dengan kondisi masyarakat pada umumnya. Pada umumnya kondisi umat Buddha berada di daerah pedesaan atau daerah yang jauh dari akses ketersediaan sarana yang memadai. d).
Faktor materi; materi pengabdian sebaiknya disesuaikan dengan obyek sasaran. Contoh ingin meningkatkan akses komunikasi internet tetapi masyarakat tidak memiliki akses internet dan kurang melek teknologi, maka materi kurang tepat sasaran. e). Faktor metode; metode pengabdian pada masyarakat hendak nya tidak terbatas pada proses pengabdian, tetapi harus mampu memberi solusi sampai pada pasca pengabdian. Contoh dalam pelatihan wirausaha roti kering dan kripik pisang, maka bukan hanya melatih pembuatannya tetapi sampai pada metode pemasarannya dan hambatan-hambatan yang mungkin terjadi.

\section{KESIMPULAN}

Peran dosen dalam pengembangan masyarakat Buddha melalui program pengabdian kepada masyarakat adalah berusaha meningkatkan dan memberdayakan masyarakat Buddha baik material dan spiritual. Secara material berusaha meningkatkan kesejahteraan sosial ekonomi masyarakat. Secara spiritual berusaha meningkatkan pengertian, pemahaman dan pengamalan ajaran Buddha. Peran dosen dalam pengabdian masyarakat yaitu memberdayakan masyarakat pada semua strata secara ekonomi, politik, sosial dan budaya, dan melakukan alih teknologi, ilmu, dan seni kepada masyarakat, untuk pengembangan martabat manusia berkeadilan gender dan inklusi sosial serta kelestarian sumber daya alam. Pengabdian kepada masyarakat di perguruan tinggi harus sesuai dengan Permenristekdikti No. 44 Tahun 
2015 tentang Standar Nasional Pendidikan Tinggi.

Terdapat beberapa faktor yang menentukan keberhasilan pengembangan masyarakat Buddha melalui program pengabdian kepada masyarakat oleh dosen di Jawa tengah yaitu: faktor dana atau anggaran sebagai subyek dampingan, faktor sasaran atau obyek pengabdian, faktor lokasi, faktor materi, dan faktor metode.

\section{DAFTAR PUSTAKA}

Direktorat Jenderal Pendidikan Tinggi, 2002, Panduan Pelaksanaan Penelitian dan Pengabdian kepada Masyarakat Edisi VI,

Direktorat Pembinaan Penelitian dan Pengabdian kepada Masyarakat.

Dumasari, 2014. Dinamika Pengembangan Masyarakat Partisipatif, Yogyakarta: Pustaka Pelajar.

Edi Suharto, 2014. Membangun Masyarakat Memberdayakan Rakyat, Bandung: PT Refika Aditama.

Hardjana, Agus M. 2003. Komunikasi Intrapersonal dan Interpersonal. Yogyakarta : Kanisius

Moh Ali Aziz, 2009. Dakwah Pemberdayaan Masyarakat, Yogyakarta: Pustaka Pesantren.
Moleong, Lexy J. 2000, Metodologi penelitian kualitatif , Bandung : Remaja Rosda Karya

Permenristekdikti Nomor 44 Tahun 2015 tentang Standar Nasional

Soekanto, Soerjono, 2002, Teori Peranan, Jakarta, Bumi Aksara

Sugiyono. 2012. Metode Penelitian Pendidikan (Pendekatan Kualitatif, Kuantitatif, dan R\&D). Bandung: Alfabeta

Thoha, Miftah. 1997, Pembinaan Organisasi (Proses Diagnosa dan Intervensi), Jakarta : PT. Raja Grafindo Persada

Undang-undang Republik Indonesia nomor 14 tahun 2005 tentang guru dan dosen, Jakarta; Cemerlang.

Zubaedi, 2013. Pengembangan Masyarakat Wacana dan Praktik, Jakarta: Kencana Prenada Media Group. 
Jurnal Pendidikan, Sains Sosial dan Agama 